\title{
Microbiological risk assessment in a coastal marine environment through the use of mathematical models
}

\author{
G. Zappalà ${ }^{1,2}$, S. Bonamano ${ }^{2}$, A. Madonia $^{2}$, G. Caruso $^{1}$ \\ \& M. Marcelli ${ }^{2}$ \\ ${ }^{1}$ Istituto per l'Ambiente Marino Costiero (IAMC), \\ National Research Council, Messina, Italy \\ ${ }^{2}$ DEB Experimental Oceanology and Marine Ecology Laboratory, \\ Tuscia University, Viterbo, Italy
}

\begin{abstract}
Most of human pathologies related to the use of marine waters for bathing purposes are caused by the presence of pathogens discharged in the aquatic environment during faecal contamination episodes. The assessment of seawater microbiological quality is conventionally performed through the search of indicator microorganisms. The use of criteria relying exclusively on the analytical evaluation of seawater quality, however, not always provides enough information about the exposure risk for human health. To better assess the sanitary risk related to the use of possibly contaminated seawaters, it is important to integrate "in situ" data with the use of mathematical models, which allow us to estimate and forecast the accumulation and the dynamics of spread and transport of potentially infectious microorganisms in relation with meteo-marine conditions. This study aimed at assessing the potential risk for human health related to pathogens in the Santa Marinella beach (Rome, Italy) during the bathing season. The coastline morphology and the presence of submerged and emerged barriers, with consequent separation of the waters nearest to the coastline from the offshore ones, reduce the possibility of water recirculation in that area. During August 2011, samples of water and sediment were drawn along the shoreline in front of Santa Marinella, and examined to measure faecal coliforms, faecal streptococci, Salmonella spp., spores of sulphite-reducing clostridia, mycetes. The collected dataset has been fed as the initial condition in a
\end{abstract}


numerical model using wind speed and direction and wave measurements to evaluate the half life of bacterial load. The study pointed out the significant effects played by meteo-marine events on the diffusion of potentially pathogenic microorganisms along the shoreline, providing useful information for the set up of measures for public health protection in the Santa Marinella area.

Keywords: coastal environment, microbial indicators, pathogens, water pollution, mathematical models.

\section{Introduction}

In recent years, the protection of human health from environmental pollution related risks has become a public concern due to the progressive increase of the anthropic pressure on coastal environments. Aquatic environments are water bodies vulnerable to all kind of pollutants, from inorganic and organic chemicals to living organisms (viruses, bacteria, protozoa). In Italy, coastal waters are mainly used for recreational purposes (swimming, diving, water skiing, etc.). The overall quality of bathing sites, either marine or freshwater, may be affected by the presence of possible pollution sources such as industry, urbanization, agricultural activities, harbour activities, depuration plants.

Contaminated seawater could induce several consequences, ranging from simple skin infections to eye irritations or severe gastro-intestinal diseases, so, knowing the microbiological quality of seawaters is fundamental to assess the sanitary and ecological risk in coastal zones.

Following the European directives for the protection of water quality (Water Framework Directive, WFD, 2000/60/EC Directive), the concept of protection of water bodies moved from a regulation based on the control of emissions to one focusing on the protection of the ecological quality of the receiving water bodies. The WFD aims at achieving, before 2015, the classification of water bodies according to several hydromorphological, chemical and biological criteria and at keeping their good environmental status from the ecological point of view, namely to ensure that all bodies have the characteristics necessary to support a biodiverse ecological community. Among the other biological components of the ecological community living in water bodies and soils, special attention should be paid to the presence of faecal indicator bacteria for their possible direct impact on human health.

The analytical evaluation of seawater quality alone, however, cannot provide sufficient information to assess the exposure risk for human health. To better assess the sanitary risk related to the use of seawaters, it is important to integrate the data collected "in situ" with the use of mathematical models, which allow us to forecast the accumulation and the dynamics of spreading and transport of potentially infectious microorganisms forced by meteo-marine conditions $[1,2]$. Mathematical models allow to track the occurrence and evolution of bacterial pollution and to prevent the outbreaks of waterborne diseases. It is therefore evident that a complete environmental management needs the availability of specific quick tools, providing integrated responses about the level of contamination and pollution and its consequences on the natural equilibrium of 
the selected ecosystems and enabling local authorities to set up suitable measures to protect and conserve areas and species which are most threatened.

In August 2011, a study was performed in Santa Marinella (Rome, Italy) to assess the presence of potentially pathogenic microorganisms, through the detection of the main faecal pollution indicators (faecal coliforms, faecal streptococci, Salmonella spp.), spores of clostridia and mycetes recognized as agents responsible for human mycoses, in a coastal marine area traditionally used for recreational activities during the period of largest use for bathing.

\section{Materials and methods}

\subsection{The study area}

Located along the Tyrrhenian coast, in the Rome province, the beach of Santa Marinella is a part of a bay about $1 \mathrm{~km}$ wide, comprised between the promontory of Cape Linaro, in the North, and Cape Anzio, in the South. It is characterized by a jagged and rocky coastline, gradually and partly replaced by a purely sandy coast, with the presence also of low calcarenites cliffs going towards the mouth of the Tiber river (about $55 \mathrm{Km}$ south). Surrounding hills partly protect the area from southwards and W-SW-wards winds, so limiting their influence on water masses.

The town of Santa Marinella is a major tourist destination, with a resident population of about 18000 people, almost doubled in summer thanks to the charm of numerous hotels and bathing facilities.

In the last fifty years, four submerged and four emerged barriers were built in front of Santa Marinella beach to reduce the incoming wave energy, so limiting erosion phenomena. Such barriers have created a semi-enclosed basin separating the coastal waters (maximum depth about $3 \mathrm{~m}$ ) from the open sea, causing, together with wind directions, especially in summer, lower potential contaminants diffusion, due to the reduced water masses renewal.

In addition, inputs from rivers and wastewaters treatment plants may increase the risk of contamination by pathogens.

\subsection{Samplings}

Water and marine sediment samples were collected throughout the month of August 2011. The sampling station was located about 10 meters from the shoreline of the beach "La Perla del Tirreno" (SP: Lat. 42.03426 N, Long. $11.86025 \mathrm{E}$ ) in the area with the largest number of bathers (Fig. 1). Measured microbiological parameters were chosen to identify main agents potentially inducing gastrointestinal infections and dermatitis (unfortunately increased in recent years among beach users).

Seawater samples were collected at a depth of about 30 centimeters below the water surface, sediment ones were taken from the first few centimeters of submerged sand. Both water and sediment samples were collected in sterile containers and stored at a temperature of $4^{\circ} \mathrm{C}$ in the dark. Once in laboratory, 


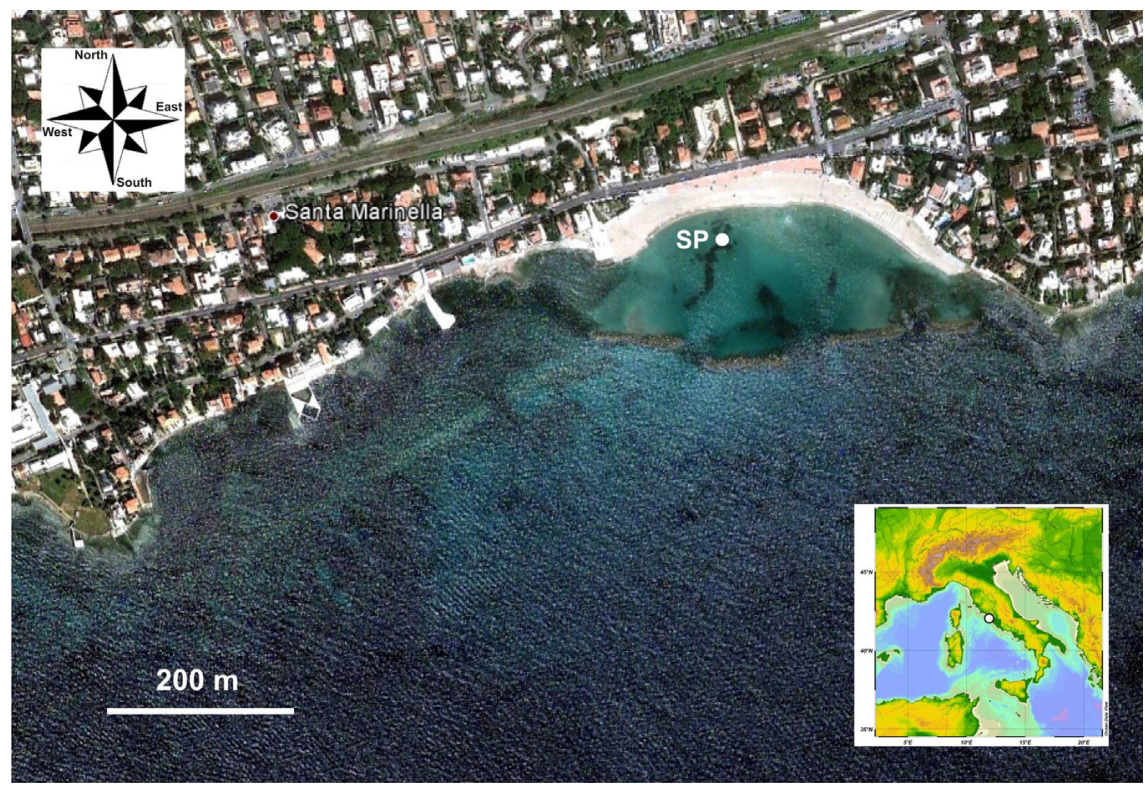

Figure 1: $\quad$ The study area (base image from Google Earth).

they were analyzed within 24 hours after sampling using specific media for each microorganism according to standard culture methods [3-5].

\subsection{Meteo-climatic conditions}

Mean and maximum daily solar radiation values are shown in Fig. 2.

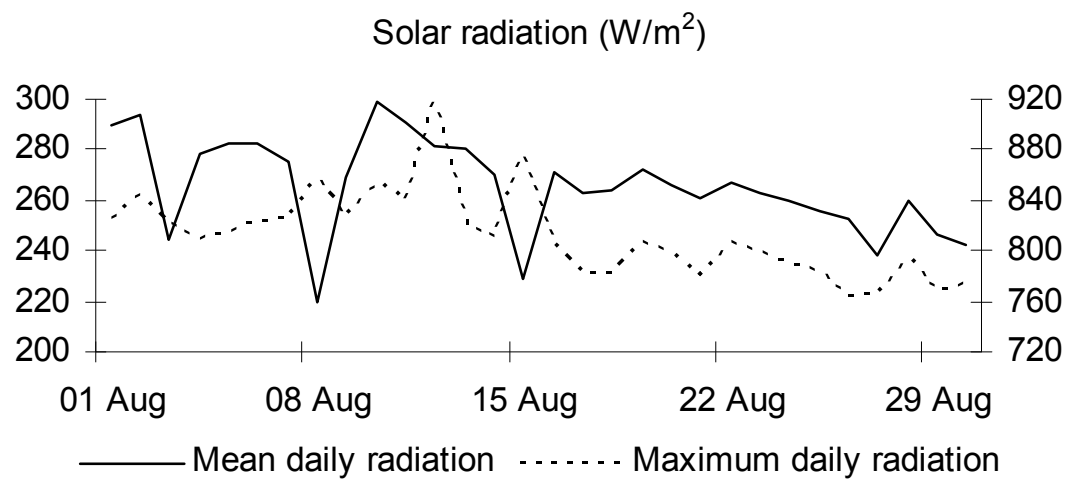

Figure 2: Mean and maximum solar radiation values recorded in August 2011 at Civitavecchia meteo station. 
Data from the weather station of the Port of Civitavecchia in the month of August 2011 highlight the prevalence of phenomena from West and South-East; the most intense winds coming from the North and North-East characterized the day of August $10^{\text {th }}$.

All the samplings were carried out in calm sea conditions, with the exception of August $8^{\text {th }}$, day during which the sea suffered intense action from NW-wards winds. It was also noted that the first half of the month was characterized by the presence of winds coming from the $1^{\text {st }}$ and $2^{\text {nd }}$ quadrants while during the second one winds coming from West were recorded.

Wind direction and speed and wave height are shown in Fig. 3.
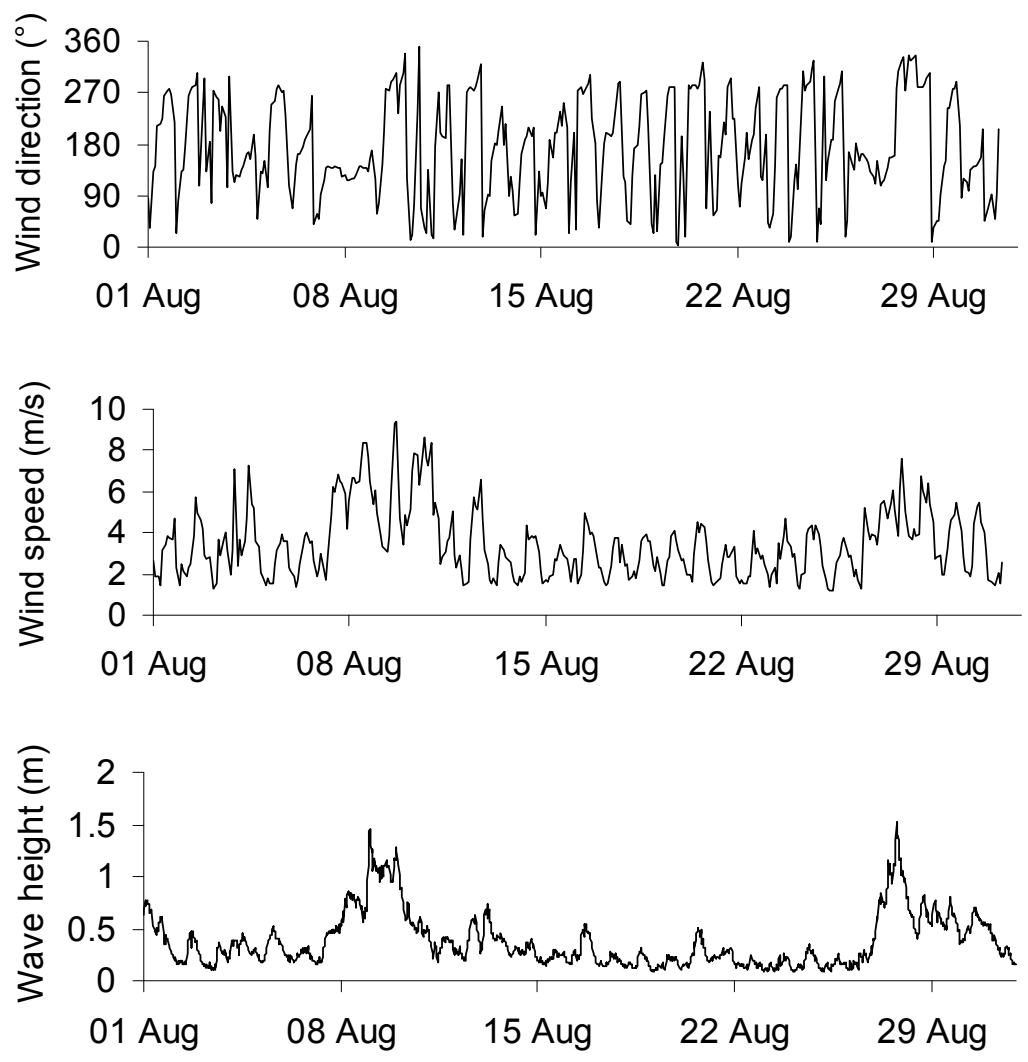

Figure 3: Wind direction and speed (Civitavecchia meteo station) and wave heights (RON-ISPRA capo linaro wave station).

\subsection{Microbiological analyses}

Microbiological analyses of water and sediment samples were performed using the standard culture methods which rely on the filtration of suitable volumes (10, 
$100 \mathrm{ml}$ ) of water samples through a $0.45 \mu \mathrm{m}$ cellulose membrane and the homogenization of the sediment samples in a 1:10 ratio with sterile seawater for the following specific procedures.

Faecal coliform counts were determined after the incubation at $44.5^{\circ} \mathrm{C}$ for 24 hours of the filters and of the suspended diluted sediment samples on plates of the selective medium m-FC broth (Difco) added with $1.2 \%$ agar. The blue colonies were considered as the target bacteria and enumerated.

Faecal streptococci were enumerated placing the filters and the suspended diluted sediment samples on plates of the selective medium Slanetz-Bartley (Oxoid), incubated at $35^{\circ} \mathrm{C}$ for 48 hours.

The search for Salmonella spp. was performed after pre-enrichment at $35^{\circ} \mathrm{C}$ for $18-24 \mathrm{~h}$ of a $300 \mathrm{ml}$ seawater volume and of $25 \mathrm{~g}$ of sediment. From the broth culture, aliquots were transferred in two enrichment media, i.e. the Rappaport broth at $42^{\circ} \mathrm{C}$ for 18 hours and the Tetrathionate broth (added with iodine solution) at $35^{\circ} \mathrm{C}$ for $24-48$ hours. From the positive broth cultures (showing bacterial growth), plates of two culture media selective for this microorganism (SS agar and Hektoen Enteric agar, Oxoid), were spread and incubated at $35^{\circ} \mathrm{C}$ for $20-24$ hours. The presumed Salmonella spp. were lactose not-fermenting, and hydrogen sulphide producing bacteria.

The detection of the Sulphite-reducing clostridia spores was performed using a Sulfite-Polymixine Sulfadiazine Agar medium.

The abundance of mycetes was determined by culture method on Czapek Dox Agar plates incubated at $22-25^{\circ} \mathrm{C}$ for 3-5 days.

\subsection{Mathematical models}

Wind and wave data collected are the forcing of high spatial resolution numerical model that calculates hydrodynamic field in the study area in order to estimate water mass transport and associated substances.

To simulate the marine currents due to wind effect ADCIRC model [6] was used. The ADvanced CIRCulation model (ADCIRC) is a two-dimensional, depth-integrated, barotropic time-dependent long wave, hydrodynamic circulation model that utilizes a high resolution $(\Delta \mathrm{x} \sim 20 \mathrm{~m})$ finite element grid. The STWAVE model [7] allowed us to estimate wave propagation in the coastal area.

STWAVE (STeady-state spectral WAVE) is a finite-difference, phaseaveraged spectral wave model that accurately simulates nearshore wave propagation and transformation including refraction, shoaling, breaking, and wind-wave generation. The obtained hydrodynamic condition was used to feed PTM (Particle Tracking Model) model [8] to describe the bacterial diffusion into the study area. The model allows us to simulate particle transport processes to determine particle fate and pathways basing on waves and currents as forcing functions.

In particular in this study four scenarios with the most frequent wind and wave conditions found during the study period were simulated (August $4^{\text {th }}, 8^{\text {th }}$, $22^{\text {nd }}$ and $25^{\text {th }}$ ). To estimate the dispersion of coliforms bacteria we used the detected concentration values as initial conditions. To simplify this first model, 
coliform dynamics were considered only dependent on physical transport processes [9], without taking into account the biological decay rate related to solar radiation and other stress sources.

\section{Results}

The concentrations of faecal coliforms of seawater samples show a variable trend during the survey, with values ranging from a minimum of 0 to a maximum of $150 \mathrm{CFU} / 100 \mathrm{ml}$ (Fig. 4). It is also possible to note how the values are far lower in the first half of the month rather than in the second, during which the maximum concentration $(150 \mathrm{CFU} / 100 \mathrm{ml})$ is recorded.

$$
\text { Faecal Coliforms } \mathrm{B} \text { Faecal Streptococci } \mathbb{N} \text { Mycetes }
$$

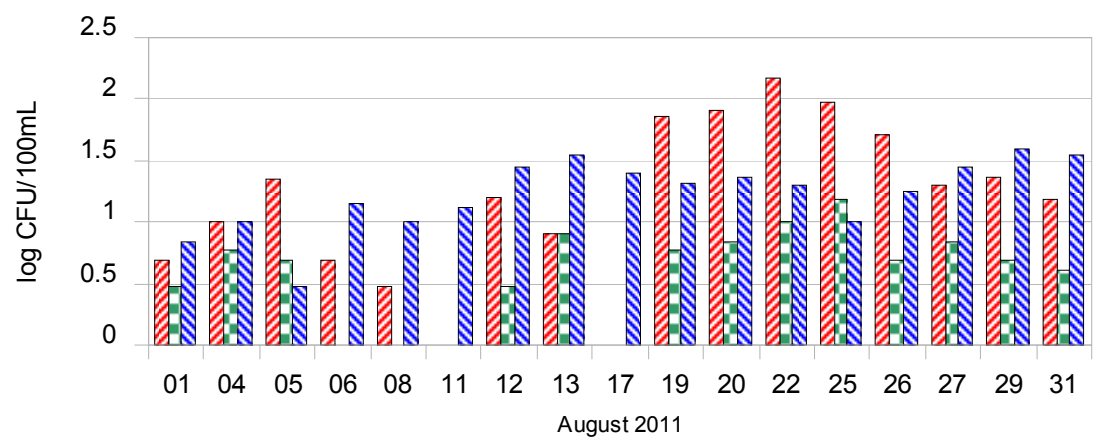

Figure 4: Results of analyses performed on water samples.

The abundance of mycetes found during the survey does not follow that observed for faecal coliforms. It varies in the range 3-35 CFU/100 ml during mid-August, then progressively decreases until $10 \mathrm{CFU} / 100 \mathrm{ml}$ on August $25^{\text {th }}$ and finally reaches a peak of $40 \mathrm{CFU} / 100 \mathrm{ml}$.

As far as the search for Salmonella spp. is concerned, throughout the period of investigation seawater samples were negative for such microorganisms. In addition, no spores of sulphite-reducing clostridia have been detected during the sampling period. The concentrations of faecal streptococci are very low with values below $15 \mathrm{CFU} / 100 \mathrm{ml}$.

The microbiological analyses performed on sediment samples, taken on August $4^{\text {th }}$ and $29^{\text {th }}$, show that the concentrations of bacterial indicators are all below the detection limit. The amount of mycetes in the sediment was found to be about half of that detected in the seawater sample taken on August $4^{\text {th }}$ (6 vs. $10 \mathrm{CFU} / 100 \mathrm{ml}$ ) and even 4 times less than that recorded on August $29^{\text {th }}$ (10 vs. $40 \mathrm{CFU} / 100 \mathrm{ml})$.

The scenarios in Fig. 5 show marine currents distribution and the microorganism fate (expressed as number of bacteria in the computational domain) in the instant in which about half of the bacterial load has left the study 
area; the colour scale reports the current speed. In the simulated periods, there is greater dispersion on August $8^{\text {th }}$ (Scenario 2); in fact, after about 4 hours, $50 \%$ of the bacterial load has left the investigated zone. The time in which the system disposes the half load is about 28 hours, 36 hours and 24 hours on August $4^{\text {th }}$ (Scenario 1$), 22^{\text {nd }}($ Scenario 3$)$ and $25^{\text {th }}$ (Scenario 4) respectively.
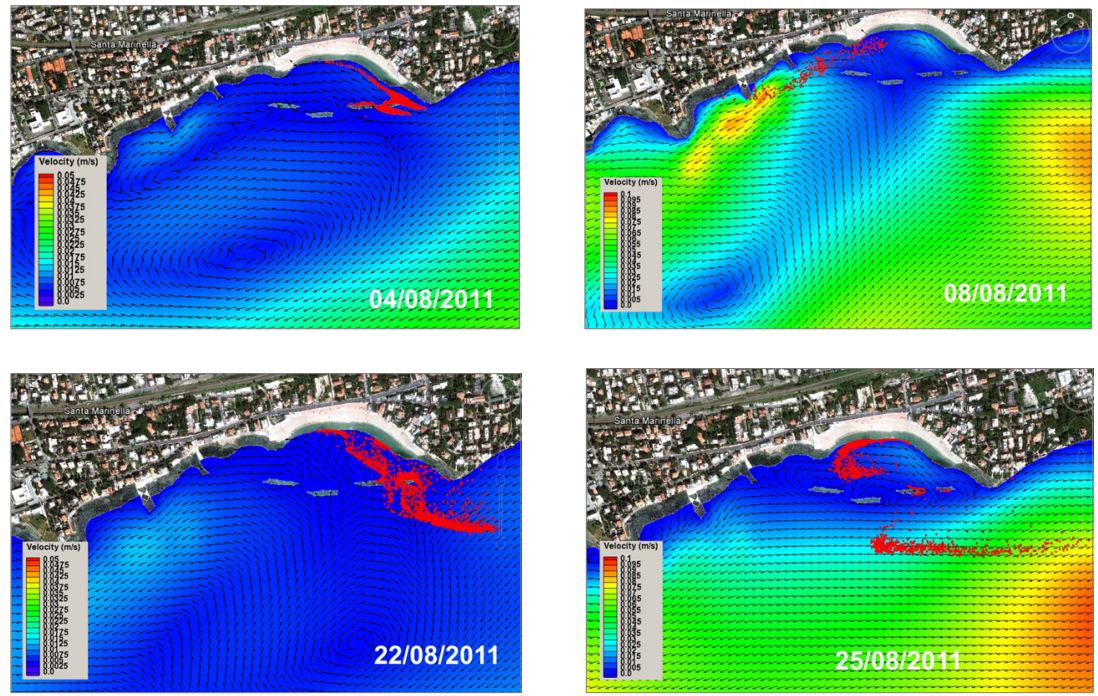

Figure 5: Model output in four days representative of hydrodynamic field and bacterial load transport.

\section{Discussion}

This study is a contribution to knowledge of risks related to the recreational use of Santa Marinella beach; collected data were used to feed mathematical models to forecast the dispersion or accumulation of pathogenic bacteria and avoid possible human health risks. The interest towards the assessment of the microbiological quality of coastal marine environments has increased since the outbreak of gastro-enteric diseases and skin dermatitis episodes in bathers, especially children, have been demonstrated to be related to the use of contaminated seawater. Epidemiological studies $[10,11]$ have suggested the strict relationships linking the massive presence of faecal contamination indicators and the occurrence of the diseases.

The analysis of the data recorded by the meteo station of the Civitavecchia Port Authority showed a dominance of winds from the $1^{\text {st }}$ and $2^{\text {nd }}$ quadrants during the first half of the month. Conversely, the second half of August was characterized by winds from the $3^{\text {rd }}$ and $4^{\text {th }}$ quadrants. The morphology of the coast, the presence of emerged and submerged barriers which surround coastal waters suggest that the currents produced by winds of $3^{\text {rd }}$ and $4^{\text {th }}$ quadrants 
determine, at the same wind intensity, an accumulation of microorganisms in the seawater closer to the beach. The winds that produce surface currents parallel to the coast line tend to disperse the contaminant charge as observed on August $11^{\text {th }}$ and $17^{\text {th }}$, when no bacterial charge was recorded.

During the investigation, the concentration of faecal coliforms in the waters close the beach of Santa Marinella shows generally lower values in the first half of the month, with an average of $8.6 \mathrm{CFU} / 100 \mathrm{ml}$, and higher values in the second one, during which there is an average concentration of $56 \mathrm{CFU} / 100 \mathrm{ml}$, with a maximum value of $150 \mathrm{CFU} / 100 \mathrm{ml}$ recorded on August $22^{\text {nd }}$.

The lower concentration of bacteria found in the first half of August is probably related to the high solar radiation values and the intense meteo-marine conditions previously reported and used as forcing for the $8^{\text {th }}$ of August simulation. Similarly, the higher coliform load in the second half of the month could be associated to the lower solar radiation, wind speed and wave heights increasing the time through which the bacteria load halves in the investigated zone as shown in the scenarios of August $22^{\text {nd }}$ and $25^{\text {th }}$.

The microorganism abundances estimated in the simulated scenarios (August $4^{\text {th }}, 8^{\text {th }}, 22^{\text {nd }}$ and $25^{\text {th }}$ ) were compared to the coliform concentration detected during the following days (August $5^{\text {th }}, 11^{\text {th }}, 25^{\text {th }}$ and $26^{\text {th }}$ ) obtaining a positive correlation $(\mathrm{r}=0.76)$. In particular the outputs of the Scenarios 2 and 4 better correlated to the observed data, because a shorter half life time (4 and 24 hours, respectively) makes the bacterial load mainly governed by physical transport processes. On the contrary, the Scenarios 1 and 3 underestimate the detected coliform abundance as biological die-off processes become dominants when a longer half life time occurs (28 and 36 hours, respectively).

Besides the wind action, the amount of enterobacteria present in the sea also depends on the processes they face once discharged. Their fate in marine environments depends on various factors (light exposure, hyperosmotic shock, nutrient availability, adsorption on suspended particles, sedimentation...) [12].

Culture methods cannot detect those cells that entered a "viable but not culturable" or a "dead" state, so underestimating the real pathogens presence; microscopical methods like the fluorescent antibody method, instead, are able to evaluate all cells [13-17].

The presence of mycetes in water, although at low concentrations (between 3 and $40 \mathrm{CFU} / 100 \mathrm{ml}$ ), should also be noted. The distribution of mycetes found during the investigation follows a trend different from faecal coliforms. Mycetes, in fact, unlike bacteria, can survive in the environment from 25 to 360 days, being able to become resistant or transform into a spore form.

The absence, in the waters as well as in the sediments, of bacteria belonging to Salmonella spp., does not indicate a critical environmental condition. The same considerations apply to the low concentrations of faecal streptococci found during the investigation.

The absence of faecal contamination indicators in sediment samples indicates that the system is capable of autodepuration from the load of entering microorganisms, which do not have time to accumulate on the bottom. In confirmation of these considerations, no spores of sulphite-reducing clostridia 
were detected both in the waters and in the sediments, so indicating that the site shows no signs of remote faecal pollution.

The concentrations of the different indicators do not show a significant relationship with the increase of human pressure of public holidays. However, during the second half of the month, when the faecal coliform values were higher, the beach was characterised by a greater overall crowding, which may result in an increased contamination likelihood.

According to a report by WHO [10], the values obtained during the investigation indicate the compliance of the Santa Marinella seawater with the standards of microbiological quality, even though the area is subject to phenomena of accumulation of potentially pathogenic organisms, thus increasing the exposure risk for the beach users.

Microbial variables could be proposed as a new useful tool to describe the environmental status, being sensitive indicators, already at an earlier phase, that a pollution has taken place in the environment. The used model was able to forecast the dynamics of dispersion of pathogens in seawater and therefore it can be proposed as an effective tool to prevent waterborne disease outbreaks. In the future, the mathematical model can be implemented after testing in coastal areas under different pollution levels. Moreover, recent trends in environmental monitoring for public health preservation (WFD) have highlighted that instead of traditional bacterial indicators like faecal coliforms other selected bacterial related targets (Escherichia coli genes or molecules) could be proposed, which are more effective bioindicators to track the occurrence and evolution of both short and large scale- bacterial pollution events, and to prevent waterborne diseases [18].

New analytical methods for environmental monitoring, like the fluorescent antibody method, are characterised by high sensitivity and speed. They may provide immediate response for the safety and/or recover of human impacted marine sites. That method, working on samples collected and preserved by fixation, allows the use of automatic water multisamplers from coastal platforms hosting also meteo stations, current-meters and other monitoring instruments [19-23]. Such equipment constitutes a more efficient way to environmental quality assessment, offering high temporal resolution in both measurements and water samples, lowering the costs. Real time transmitted data enable not only to nowcast environmental conditions, but also to feed and validate forecasting models, so offering successful tools for early warning of pollution phenomena and for the screening of polluted coastal areas.

More detailed studies, based on mathematical models, could shed more light on the effect of weather and sea conditions on the phenomena of potentially pathogenic bacterial spread along the coast.

\section{References}

[1] Gourmelon M., Lazure P., Hervio-Heath D., Le Saux J. C., Caprais M. P., Le Guyader F. S., Catherine M., and Pommepuy M. Microbial modelling in coastal environments and early warning systems: useful tools to limit 
shellfish microbial contamination. Safe management of Shellfish and Harvest Waters. eds. G. Rees, K. Pond, D. Kay, J. Bartram and J. Santo Domingo, IWA Publishing: London, pp. 297-318, 2010.

[2] Steets B.M., Holden P.A. A mechanistic model of runoff-associated faecal coliform fate and transport through a coastal lagoon. Water Research 37, pp. 589-608, 2003.

[3] APAT-CNR-IRSA, Manuali e Linee Guida, Metodi Analitici per le Acque 29/2003, III; sezione 6000 Metodi microbiologici- parte generale; sezione 7000 Metodi per la determinazione dei microrganismi indicatori di inquinamento e di patogeni, 2003.

[4] CNR-IRSA, Metodi analitici per i fanghi, Quaderno 64, Volume 1, 1983.

[5] Istituto Superiore di Sanità (ISTISAN), Metodi analitici di riferimento per le acque destinate al consumo umano, Rapporti ISTISAN, 00/14, 2000.

[6] Luettich, R.A., Westerink, J.J. and Scheffner, N.W., ADCIRC: An advanced three-dimensional circulation model for shelves, coasts, and estuaries, Report 1: Theory and methodology of ADCIRC-2DDI and ADCIRC-3DL. Technical Report DRP-92-6, U.S. Army Engineer Research and Development Center: Vicksburg, MS, pp. 1-137, 1992.

[7] Smith, J.M., Sherlock, A.R. and Resio, D.T., STWAVE: Steady-State Spectral Wave Model user's guide for STWAVE Version 3.0, ERDC/CHL SR-01-01, U.S. Army Engineer Research and Development Center: Vicksburg, MS, 2001.

[8] MacDonald, N. J., Davies, M.H., Zundel, A.K., Howlett, J.D., Lackey, T.C., Demirbilek, Z., and Gailani, J.Z., PTM: Particle tracking Model; Report 1: Model theory, implementation, and example applications. ERDC/CHL TR-06-20, U.S. Army Engineer Research and Development Center: Vicksburg, MS, 2006.

[9] Fiandrino, A., Martin, Y., Got, P., Bonnefont, J.L., and Troussellier, M., Bacterial contamination of Mediterranean coastal seawater as affected by riverine inputs: simulation approach applied to a shellfish breeding area (Thau lagoon). Water Research, 37, pp. 1711-1722, 2003.

[10] World Health Organization, Guidelines for safe recreational water environments, Volume 1, Coastal and fresh waters, WHO: Geneva, 2003.

[11] Prüss, A., Review of epidemiological studies on health effects from exposure to recreational water. International Journal of Epidemiology, 27, pp. 1-9, 1998.

[12] Trousselier, M., Bonnefont, J.L., Courties, C., Derrien, A., Dupray, E., Gauthier, M., Gourmelon, M., Lebaron, P., Martin, Y., and Pommepuy, M., Response of enteric bacteria to environmental stresses in seawater. Oceanologica Acta, 21, pp. 965-981, 1998.

[13] Caruso, G., Zaccone, R., Monticelli, L., Crisafi, E., and Zampino, D., Bacterial pollution of Messina coastal waters: a one year study. Microbiologica, 23, pp. 297-304, 2000.

[14] Caruso, G., Zaccone, R., and Crisafi, E., Use of the indirect immunofluorescence technique for detection and enumeration of 
Escherichia coli in seawater samples. Letters in Applied Microbiology, 31, pp. 274-278, 2000.

[15] Caruso, G., Mancuso, M., and Crisafi, E., Combined fluorescent antibody assay and viability staining for the assessment of the physiological states of Escherichia coli in seawaters. Journal of Applied Microbiology, 95, pp. 225-233, 2003.

[16] Caruso, G., Denaro, R., Genovese, M., Giuliano, L., Mancuso, M., and Yakimov, M.M., New methodological strategies for detecting bacterial indicators. Chemistry and Ecology, 20, pp. 167-181, 2004.

[17] Caruso, G., Zappalà, G., Caruso, R., and Crisafi, E., Assessment of Escherichia coli viability in coastal Sicilian waters by fluorescent antibody and b-glucuronidase activity methods, Proc. of the $6^{\text {th }}$ International Conference on Environmental Problems in Coastal Regions, ed. C.A. Brebbia, WIT Press: Southampton, 88, pp. 57-66, 2006.

[18] Bonadonna, L., Il rischio associato alle attività di balneazione e le difficoltà legate alla sua previsione attraverso l'uso degli indicatori di contaminazione fecale, Annali Istituto Superiore di Sanità, 39, pp. 47-52, 2003.

[19] Zappalà, G., Caruso, G., and Crisafi, E., Design and use of advanced technology devices for sea water monitoring. Operational Oceanography. Implementation at the European and Regional Scales, eds. N.C. Flemming, S. Vallerga, N. Pinardi, H.W.A. Behrens, G. Manzella, D. Prandle, J.H. Stel, Elsevier Oceanography Series, 66, pp. 273-280, 2002.

[20] Zappalà, G., Caruso, G., and Crisafi, E., The "SAM" integrated system for coastal monitoring. Proc. of the $4^{\text {th }}$ International Conference on Environmental problems in Coastal Regions, ed. C.A. Brebbia, WIT Press: Southampton, 8, pp. 341-350, 2002.

[21] Zappalà, G., Caruso, G., Azzaro, F., and Crisafi, E., Integrated environment monitoring from coastal platforms. Proc. of the $6^{\text {th }}$ International Conference on the Mediterranean Coastal Environment, MEDCOAST 03, ed E. Ozhan, MEDCOAST, Middle East Technical University: Ankara, 3, pp. 2007-2018, 2003.

[22] Zappalà, G., Caruso, G., and Crisafi, E., Coastal pollution monitoring by an automatic multisampler coupled with a fluorescent antibody assay. Proc. of the $5^{\text {th }}$ International Conference on Environmental problems in Coastal regions, eds. C.A. Brebbia, J.M. Saval Perez, L. Garcia Andion and Y. Villacampa Esteve, WIT Press: Southampton, 10, pp. 125-133, 2004.

[23] Zappalà, G., Caruso, G., Azzaro, F., and Crisafi, E., Marine environment monitoring in coastal Sicilian waters. Proc. of the $8^{\text {th }}$ International Conference on Water Pollution: Modelling, Monitoring and Management, ed. C.A. Brebbia, WIT Press: Southampton, 95, pp. 337-346, 2006. 